\title{
REPORT FROM INDIA
}

\author{
By E. P. GeE
}

Any news of wild life preservation (or lack of it) in India, as in other parts of South Asia, must be examined against the background of a young democratic and liberal administration which has not sought to restrict the issue of licenses for firearms and which has encouraged rapid development and industrialization. Those outside the sanctuaries have become considerably human population and spread of villages and agriculture, and an equal increase in numbers of domestic cattle and buffaloes with consequent opening up of new areas for grazing.

With these changes it is inevitable that there should now be great pressure from all sides on the shrinking wild life population. Those outside the sanctuaries have become considerably reduced in numbers in nearly all parts of the country, while those which are supposedly protected inside the sanctuaries have in many cases suffered losses from poachers and others.

Unless great care and vigilance are exercised by the State Governments of the Indian Union, the wild life of this country will be in danger of complete extermination in the not-far-distant future.

\section{The Great Indian One-horned Rhinoceros}

The numbers of this species of rhino are believed to be on the increase, as far as India is concerned. Poaching for the horn is still going on in Assam, in Manas Sanctuary, and even in Kaziranga ; and it may also be happening in Bengal. But, although the number of rhino in Manas Sanctuary has probably decreased in recent years due to lack of full enforcement of the law, my impression is that in Kaziranga rhino have increased considerably. Two visits to Kaziranga in May, 1961, have convinced me that this species, as well as the Indian Swamp Deer, is on the increase there in spite of sporadic poaching.

Although Nepal does not come into the purview of this note, reference could well be made here of the position of the rhino in that country. In my Report of $1958 \mathrm{I}$ estimated that there were $\mathbf{3 0 0}$ rhino in that country, and this estimate was supported by the figures of those persons most qualified to express an opinion. It is extremely difficult to get any reliable information from Nepal on the subject, but from private sources (March, 1961) I understand that the number of rhino has decreased since the spring of 1958 and that it may now be as low as 125 . 
Also that everything is once again " in the melting pot", and that there are no Shooting Rules, no Forest Act, and no Wild Life Preservation Act.

The fact that a rhino, officially " protected" in Nepal, was shot in an organized shoot early in 1961 indicates that no serious attempt at wild life conservation is yet being made in that country. It is hoped that the subsequent world-wide reactions against the killing of this cow rhino may somehow be effective in inducing the authorities in Nepal to fall into line with the rest of the world in conserving fast-disappearing species.

\section{The Indian Lion}

I visited the Gir Forest for a few days early in November, 1960, sponsored by the Survival Service Commission of the International Union for the Conservation of Nature. This visit was valuable for two reasons : firstly the 500-square-mile area of the Gir Forest had become part of the newly-created state of Gujarat early in 1960, and secondly there had been reports of poisoning of lions by disgruntled villagers who had had their cattle and buffaloes killed.

With regard to the new administrative situation, I am glad to be able to report that the Conservator of Forests (Junagadh Circle), the Divisional Forest Officer (Gir Division), and the Sub-Divisional Forest Officer (Sasan Gir) all appeared to be interested in the preservation of the lions and alive to the dangers that beset them. Gujarat was the only State of India (apart from the host State, Madras) which was represented at the meeting of the Indian Board for Wild Life at Ootacamund in February 1961, by all three persons concerned with preservation-the Forest Minister, the Chief Conservator of Forests and the Wild Life Preservation Officer. There is a proposal to upgrade the Gir Forest area into a sanctuary or national park.

With regard to the lion population, there have been reports in the press from reputable local naturalists that many lions have been poisoned in the last few years, and that the number of lions may now be as low as 100. The official Forest Department view, however, is that only a few (two lions, two lionesses and three cubs) have been poisoned and those on the fringes of the area, and that the number of lions now is about 250 . Obviously it may be assumed that the real truth is somewhere in between these two figures. The 1950 rough census gave the numbers as 240, and the rough census of 1955 put the figure at 290. An effort is being made to conduct a census during April-May 1961, and reports of this are still awaited. 


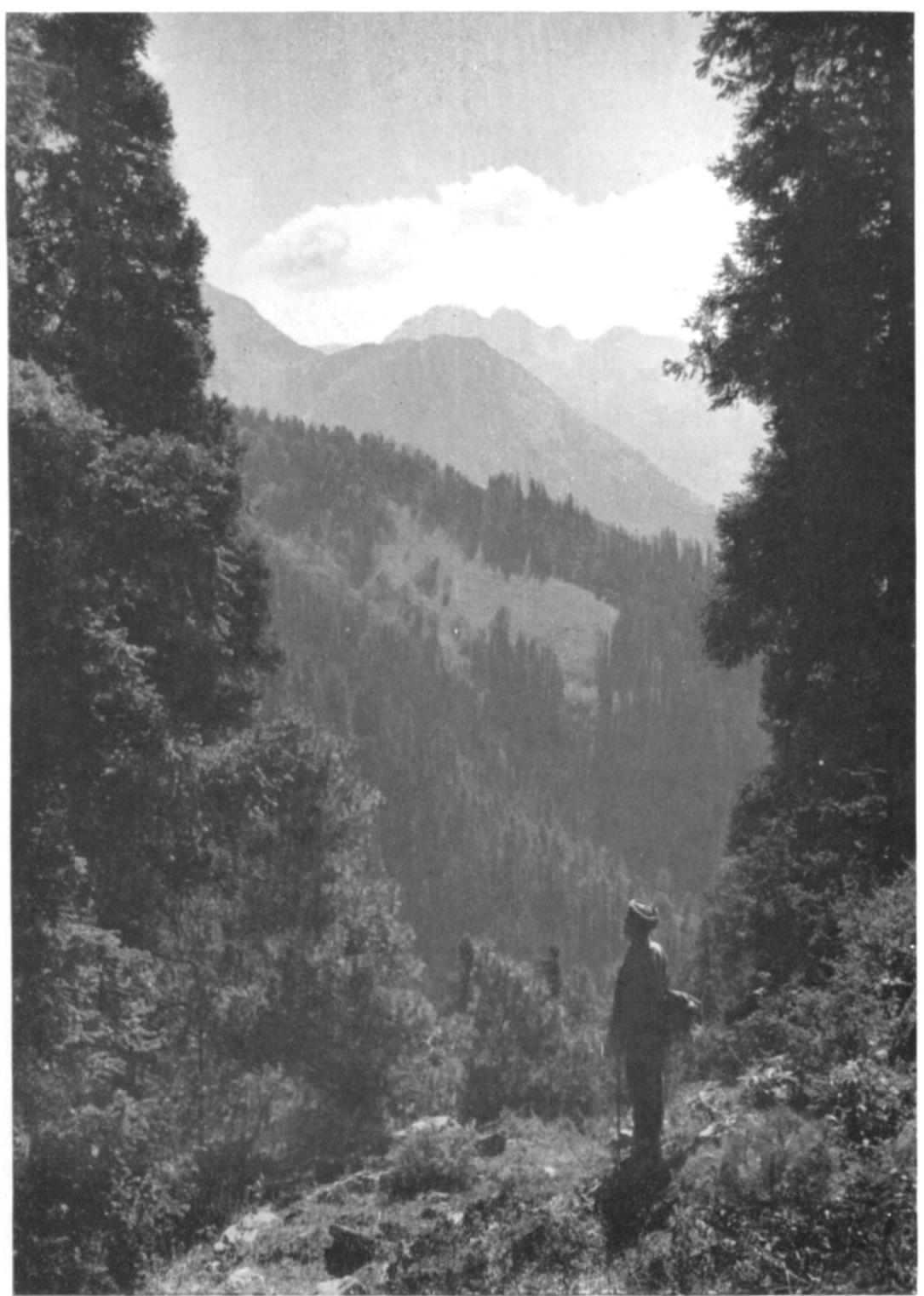

Photo: E. P. Gee.

UPPER I)ACHIGAM IN SEPTEMBER. SUMMER RANGE OF THE KASHMIR STAG. 


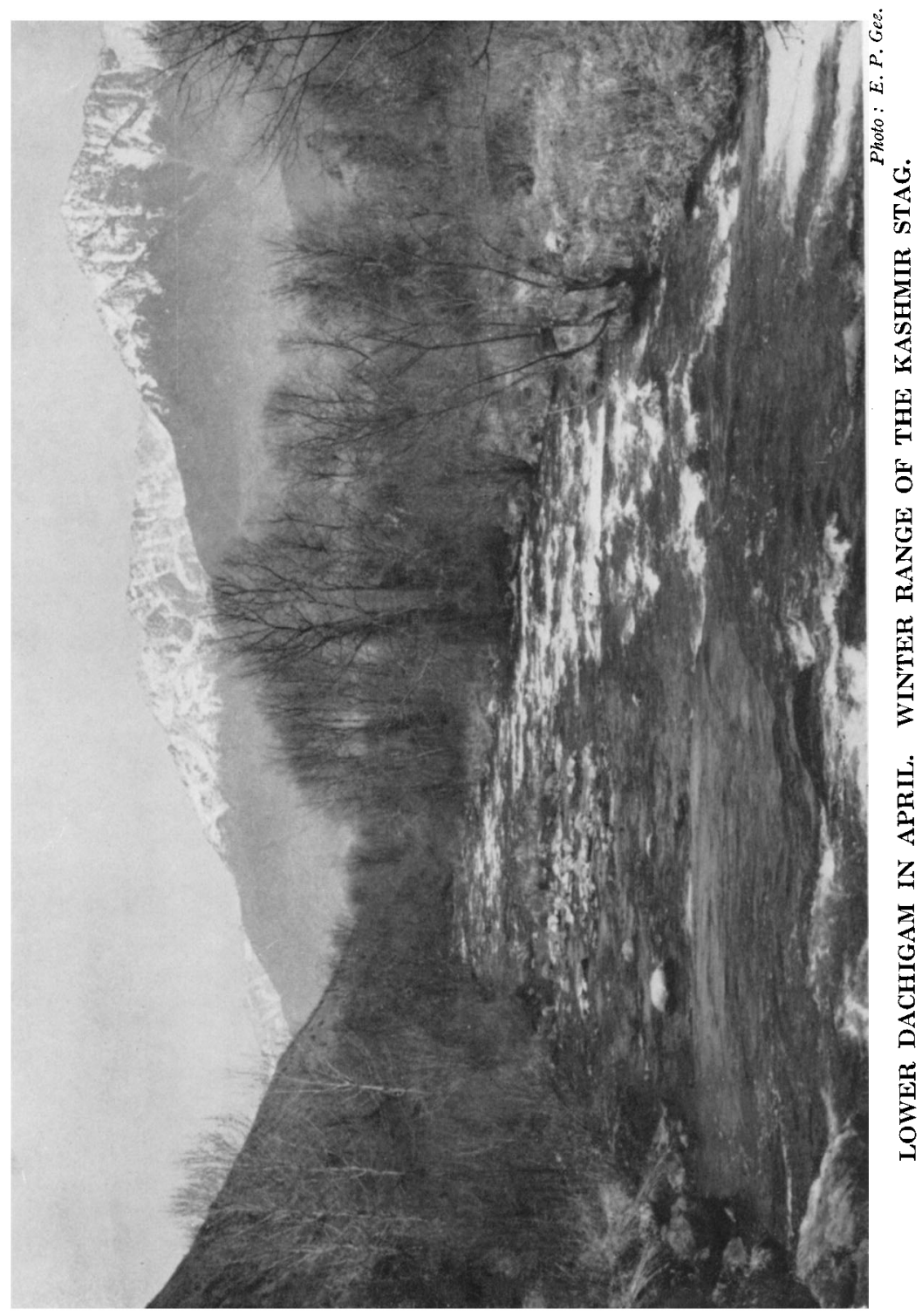


My own impression is that probably 250 to 300 lions may be rather a large population for the area concerned, in view of the scarcity of natural game for them to feed on, resulting in so many domestic cattle and buffaloes being killed. The Indian Board for Wild Life has been concerned with the problem of how to keep the numbers within reasonable limits. At the same time the local villagers and others obviously must not be allowed to take the law into their own hands : any " management" of the area and its wild life must be done only by the proper authorities.

During my brief visit I was able to see at close quarters three lionesses with three cubs, and also a pride consisting of one maned lion and three lionesses with seven cubs. The number of cubs seen was very gratifying, and my visit was made even more worthwhile by the very fine and well organized "lionshow" which I saw-and which visitors from any part of the world can see.

The lion and two lionesses which were captured in the Gir Forest and released (re-introduced) into Chandraprabha Sanctuary in Uttar Pradesh in 1957 are reported to be doing quite well. A cub was seen with one of the lionesses in February 1958, but subsequently was not seen again. In the spring of 1960 the other lioness was seen with two cubs. The latest news from the Government of Uttar Pradesh is that these lions are doing well and that the experiment is progressing satisfactorily. There are plans for clearing the area of tigers, leopards and wild dogs and to construct artificial lakes and salt-licks.

\section{The Kashmir Stag}

A brief visit (also on behalf of I.U.C.N.) to Kashmir and its Dachigam "Sanctuary" in November 1960 produced very disappointing results. Firstly I found that, in spite of Dachigam being officially said to be a sanctuary and the stag protected, in actual fact there was no act or even gazette notification in existence for protecting either the "sanctuary" or the stag. Secondly I was informed that the physical " count" which was supposed to have been done in the winter of 1957-58, after which the figure of approximately 550 head had been given to me, had been in reality only an estimate. And thirdly $I$ was told that poaching of the stag was still going on and even that permits were being officially issued for the shooting of one or two stags per year by very important persons.

To add to this depressing news, Colonel H. Nedou, who was 
game warden of Kashmir from 1950-1954 and whose knowledge of the fauna of that State is probably unequalled, told me that he estimated that there were only about $250 \mathrm{Kashmir}$ stags alive today. If this estimate is a true one, then the position of this rare and beautiful deer is very precarious indeed. Unless the Government of Jammu and Kashmir can immediately enact and enforce legislation to ensure the inviolability of Lower and Upper Dachigam and to protect the stag fully, this noble and valuable deer will inevitably go the same way as the Shou of Sikkim and Tibet.

It is difficult to understand how a State which is encouraging tourism should not have taken effective steps to preserve its wild life, particularly a rare and vanishing species which could be a major attraction to visitors from all over the world. I have myself visited Kashmir five times : in the months of April, May, September, October and November. I have seen the stag in Lower Dachigam in April and November, and in the alpine meadows and birch forests of Upper Dachigam in September. I can think of no lovelier place in the world than these parts of Kashmir, and no animal of greater magnificence than the Kashmir stag.

On this visit I was particularly struck by the extraordinary beauty of Lower Dachigam "Sanctuary" in its autumnal array of colours. It defies all attempts at description. And in the undergrowth of willows and shrubs I caught a fleeting but never-to-be-forgotten glimpse of a grand ten-pointer in company with about twelve hinds and fawns. Is it not possible that this fine ten-pointer has since then fallen a victim to a bullet from the gun of a poacher? Or of a v.i.p. with a "legally" issued permit? When a wild life species is in danger of extermination, is there much distinction between a poacher (who is probably unaware of the pressing need for conservation of a fast-disappearing species) and a v.i.p. who must by now be wise to the fact that India is losing much of her fauna?

Surely the point has now been reached when the Kashmir stag should no longer be regarded as "royal game" by the authorities in Kashmir, as it was in the olden days. Unless all issuing of permits to v.i.p.'s for shooting stags can be stopped immediately, and unless poaching by villagers and "gujars" (graziers) can be checked effectively, then another fine deer is going to be lost to the world for ever. 